\title{
Libel and the Reporting of Rumor
}

\author{
On October 5, 1981, the Washington Post reported a rumor that Presi-
} dent Jimmy Carter had bugged the Washington residence of Presidentelect Ronald Reagan during Reagan's preinauguration stay. ${ }^{1}$ A furor quickly ensued. President Garter threatened to sue the Post for libel, ${ }^{2}$ dropping the threat only after its publisher apologized two weeks later. ${ }^{3}$ The Post was harshly criticized for publishing what it admitted was rumor, ${ }^{4}$ and the criticism increased when the newspaper acknowledged in an

1. The report appeared in a gossip column called "The Ear," which the Post published three times a week. The report read in full:

Y'ALL COME ... Well. Quite a little ripple among White Housers new and old. That tired old tale about Nancy dying for the Carters to blow out of the White House as swiftly as possible is doing a re-run-with a hot new twist. (Remember the uproar? Nancy supposedly moaned that she wished Rosalynn and Jimmy would skip out before the Inauguration, so she could pitch into her decor chores.) Now, word's around among Rosalynn's close pals, about exactly why the Carters were so sure Nancy wanted them Out. They're saying that Blair House, where Nancy was lodging - and chatting up First Decorator Ted Graber-was bugged. And at least one tattler in the Carter tribe has described listening in to the Tape Itself. Now, the whole story's been carried back to the present White House inhabitants, by another tattler. Ear is absolutely appailed. Stay tuned, uh, whoever's listening.

The Ear, Wash. Post, Oct. 5, 1981, at D1, col. 1.

2. Wash. Post, Oct. 9, 1981, at A3, col. 1. President Carter demanded that the Post retract the item and apologize for publishing it. The Post initially responded that it stood behind the report. See id., Nov. 12, 1981, at A4, col. 1 .

3. Wash. Post, Oct. 23, 1981, at A1, col. 5. The apology came in the form of a letter from Donald E. Graham, publisher of the newspaper, to both President Carter and his wife, Rosalynn. President Carter dropped his plans to file suit the next day. Id., Oct. 25, 1981, at A7, col. 2.

4. The Post did not report that President Carter had bugged Blair House; it reported that a story was circulating in Washington that the bugging had taken place. Id., Oct. 5, 1981, at D1, col. 1 ("[W]ord's around among Rosalynn's close pals ....."). In an editorial prompted by President Carter's complaint, the Post drew a distinction between reporting information as rumor and reporting information as fact:

The point was that a story was circulating . . . .

It is one thing, however, to read that item to say that such a tale is circulating and being given currency by estimable public figures who repeat it -and quite another to conclude from this that the place was in fact bugged and that the Carters did in fact perpetrate such a scheme.

F.Y.I., Wash. Post, Oct. 14, 1981, at A24, col. 1.

Several prominent journalists were critical of the gossip column and the printing of rumors. Syndicated columnist George F. Will, whose work appears in the Post, said: "The presence of a gossip column on a great paper . . . is inconsistent with the mission and dignity of the Washington Post.' " Griffith, Going Eyeball to Eyeball-and Blinking, TIME, Nov. 2, 1981, at 122. Thomas Griffith, the media commentator for Time, questioned the journalistic ethics of gossip columnists: "Gossip writing requires snoopy eavesdropping, a delight in malice and a readiness to go into print with one side, or one piece of a story." Id. President Carter's former press secretary, Jody Powell, suggested that the 
editorial that it had printed the item while not believing it to be true. ${ }^{5}$

Almost lost in the discussion of journalistic ethics was a perplexing legal question: To what extent does the First Amendment protect a newpaper that publishes rumor, especially rumor that the newspaper does not believe to be true? ? $^{6}$ This Note explores the law of libel as it applies to publications based on rumor and other unorthodox sources. Part I of the Note discusses the rationale for publishing reports of rumors. Part II examines the liability the publisher of rumor may incur under current libel law. It concludes that current libel law offers inadequate protection for the publisher. Part III develops a standard of liability for publishing rumor that would address this inadequacy.

\section{Reporting Rumor}

The characteristic that distinguishes rumor from other types of reports is its lack of a solid factual basis. ${ }^{7}$ It is this characteristic that has made the publishing of rumor a controversial practice among journalists; ${ }^{8}$ a traditional tenet of their craft has been that they print only the truth. ${ }^{9}$ Yet

rumor should have been investigated more thoroughly and the resulting story, if true, reported on the Post's front page. N.Y. Times, Oct. 16, 1981, at A22, col. 1.

5. In concluding its editorial, the Post wrote, "[The column] said there was a rumor around. There was. Based on everything we know of the Carter instinct and record on this subject, we find that rumor utterly impossible to believe." F.Y.I., supra note 4. The implication of this admission was that if the Post considered a rumor to be of interest to the public, it would report the rumor's existence regardless of the rumor's truth. Columnist Will charged that this policy gave "your gossip columnist a license to disseminate lies." Griffith, supra note 4, at 122 . In an advertisement, Mobil Corp. sarcastically saluted the Post "for extending the frontiers of journalism" and suggested that the Post establish a rating system for its articles to let "the reader know how much credence to attach to a given story." N.Y. Times, Oct. 29, 1981, at A27, col. 4. Post Publisher Graham backed away from the editorial's implications in his letter of apology to the Carters, stating that the editorial "did not intend to suggest that the paper prints rumors which it knows to be false, because that is not the policy of The Washington Post." Wash. Post, Oct. 23, 1981, at A1, col. 5. An excellent summary of the episode appeared in N.Y. Times, Nov. 18, 1981, at A24, col. 5.

6. An exception was a thoughtful article in the New York Times which analyzed both the journalistic and legal questions raised by the episode. N.Y. Times, Oct. 16, 1981, at A22, col. 1.

7. See G. AlLPORT \& L. POSTMAN, THE PSYCHOLOGY OF RUMOR at ix (1947) (defining rumor as "specific (or topical) proposition or belief, passed along from person to person, usually by word of mouth, without secure standards of evidence being present"); T. KNOPF, RUMORS RACE AND RIOT 2 (1975) (central feature of rumor is that it is unverified); R. ROSNOW \& G. FINE, RUMOR AND GOSSIP: THE SOCIAL PSYCHOLOGY OF HEARSAY 11 (1976) (listing lack of factual basis as one of four characteristics of rumor). Another major characteristic of rumor is that it has no identifiable source but rather is repeated by many people. See Smith v. Moore, 74 Vt. 81, 86, 52 A. 320, 321 (1902) (rumor is "a flying or popular report, the common talk . . . not the remarks of a single person").

8. See J. HOHENBERG, THE PROFEsSIONAL JOURNALIST 120 (4th ed. 1978) ("The use of rumors in news stories causes endless trouble, even when the rumors turn out to have some substance."); N.Y. Times, Oct. 16, 1981, at A22, col. 1 (many news organizations shun use of rumors); supra note 4; see also L. CANNON, REPORTING: AN INSIDE VIEW 267 (1977) (work of columnist who publishes unsubstantiated material said by editor to contain "very wild stuff that we don't publish"); H. GANS, DECIDING WHAT'S NEWS 134 (1979) (publisher of unsubstantial material termed "gossip-monger" by many journalists). But see L. CANNON, supra, at 267-68 (publisher of rumor necessary "to print a story when newspapers won't do it on their own"); H. GANS, supra, at 134 (same).

9. See, e.g., COMMISSION ON FREEDOM OF THE PRESS, A FREE AND RESPONSIBLE PRESS 21 (1947) 
a knowledge of rumors often is central to understanding important events. Rumor can have a significant influence on individual and group behavior: ${ }^{10}$ Rumors have affected the operation of individual businesses ${ }^{11}$ and the stock market, ${ }^{12}$ instigated riots, ${ }^{13}$ and provided the mechanism for political manipulation. ${ }^{14}$ Such events fit within any definition of newsworthiness, ${ }^{15}$ and a reporter who wishes to convey the most complete

(media's responsibilities to society include presenting "truthful, comprehensive, and intelligent account of the day's events in a context which gives them meaning"); J. JOHNSTONE, E. SLAWSKI \& W. BOWMAN, THE NEWS PEOPLE 114 (1976) ("neutral" journalism characterized by strict adherence to objectivity, factual accuracy, and verification of information); $c f$. id. at 176 (critics of neutral journalism maintain that objectivity is unattainable but still stress fairness and accuracy); Wall St. J., May 14,1981 , at 1, col. 1 ("New Journalism" proponents adopt freer literary style but still demand accuracy). But see G. ALLPORT \& L. POSTMAN, supra note 7, at 187 (what press presents as truth may border on rumor due to inherent problems with process of news reporting).

10. The motivations behind the generation and spread of rumors are complex. A primary factor, cited by both psychologists and sociologists, is the need to deal with ambiguity on both an individual and a collective level. For the individual, a rumor satisfies an emotional and intellectual desire to find a plausible explanation for a confusing situation-the successful rumor justifies why the individual feels a certain way and gives him a verbal outlet for his anxiety. See G. ALLPORT \& L. POSTMAN, supra note 7, at 37; R. ROSNOW \& G. FINE, supra note 7, at 52-54. On a group level, rumormongering has been described as a means of group problem-solving. In order for members of the group to act in concert when confronted by an unknown situation, the group must develop a common conception of the problem. This is done by comparing impressions through the spreading of rumors. Implausible rumors are eliminated as the group builds a consensus. See T. SHIBUTANI, IMPROVISED NEWS: A SOCIOLOGICAL STUDY OF RUMOR 163-83 (1966).

11. While stories of impending takeovers, closings, and changes in financial condition are the most common form of such rumors, this list does not exhaust their variety. See, e.g., Wall St. J., Oct. 10, 1980, at 32, col. 4 (rumors of romantic relationship between head of major corporation and new vice president led to vice president's resignation); id., May 14, 1980, at 20, col. 2 (Xerox Corp. fights rumor linking photocopies, cancer); see also id., Feb. 6, 1979, at 1, col. 1 (describing strategies used by firms to combat rumors).

12. See Wall St. J., May 15, 1981, at 1, col. 5 (stock speculators circulated rumors of Federal Reserve chairman's resignation to make profit); id., Sept. 5, 1980, at 17, col. 1 (rumor that presidential candidate Ronald Reagan suffered heart attack caused plunge in stock prices); id., Apr. 30, 1980, at 17 , col. 1 (small investors ignore brokers' advice for rumors, tips). In the 1920's, journalists sometimes were the instruments of speculators attempting to manipulate stock prices through planted stories. Newspapermen were reportedly given approximately $\$ 100,000$ in bribes to print stories as part of one manipulation scheme. See R. SOBLE, AMEX: A HISTORY OF THE AMERICAN STOCK EXCHANGE, $1921-1971$, at 84-86 (1972).

13. Cf. T. KNOPF, supra note 7, at 107-67 (rumors help prepare way for riots). For example, rumors of police brutality were invoked to explain the instigation of the 1965 riot in Watts, a black residential area of Los Angeles. Sce R. ROSNOW \& G. FINE, supra note 7, at 58.

14. Rumors may play a major role in feuds among government officials: "In the right hands at the right time, the strategically placed political rumor is perhaps the most subtle and lethal weapon in the arsenal of the Washington bureaucrat. This kind of rumor is part of the serious maneuvering and jockeying for power in Washington." N.Y. Times, Nov. 3, 1981, at B10, col. 3; see also Gorman Towers, Inc. v. Bogoslavsky, 626 F.2d 607 (8th Cir. 1980) (holding privileged defendant's attempt to influence zoning legislation by spreading false derogatory rumors about proposed apartment complex); Wall St. J., Nov. 6, 1981, at 34, col. 3 (discussing use of rumors in battle between Secretary of State Alexander Haig and White House officials).

15. There is no standard definition of newsworthiness, but most definitions stress the number of people interested in or affected by the event in question. According to the Commission on Freedom of the Press, journalists use "news" to mean "something that has happened within the last few hours which will attract the interest of the customers. The criteria of interest are recency or firstness, proximity, combat, human interest, and novelty." COMMISSION ON FREEDOM OF THE PRESS, supra note 9, at 54-55; see also L. CANNON, supra note 8, at 15-25 (discussing factors used by media to select stories 
account of these events therefore must publish rumors.

Because of its uncertain factual basis, however, the publication of rumor entails a variety of risks. Printing unsubstantiated information may unjustly injure an individual's reputation. ${ }^{16}$ On a broader scale, publishing rumors may engender harmful confusion in times of emergency, ${ }^{17}$ or undermine the operation of valuable institutions. ${ }^{18} \mathrm{~A}$ publisher also must consider whether reporting rumor will endanger his publication's credibility. ${ }^{10}$

To minimize these dangers, a publisher circulating a report based on rumor should identify it as such. ${ }^{20}$ Such attributions serve to inform the reader about the reliability of the information being reported. ${ }^{21}$ The source of a story is a major factor considered by a publisher in judging the

for publication); J. HOHENBERG, supra note 8 , at 88 (characterizing news as an accurate, interesting, and timely report that explains an event).

16. A classic example of this problem occurred during the 1972 presidential election. A syndicated columnist published a report that Senator Thomas Eagleton of Missouri, the Democratic vice-presidential nominee, had been arrested for drunken and reckless driving in the 1960's. The report was yet another blow to Eagleton, who had announced several days earlier that he had been hospitalized three times for treatment of nervous exhaustion and fatigue. The rumor was later shown to be false. The columnist issued an apology and retraction. See Wash. Post, July 28, 1972, at A12, col. 1 (Eagleton denies rumor published by columnist that he had been arrested for drunken and reckless driving); Cheshire, Anderson on Eagleton: A Charge That Didn't Stand Up, Wash. Post, July 29, 1972, at A16, col. 3 (news reporter explains why she did not report Eagleton rumor); Wash. Post, Aug. 2, 1972, at A4, col. 1 (columnist retracts Eagleton story and apologizes for its publication).

17. See E. DANZIG, THE EFFECTS OF A THREATENING RUMOR ON A DISASTER-STRICKEN COMMUNITY (1958); O. LARSEN, RUMORS IN A DISASTER (1954); R. ROSNOW \& G. FINE, supra note 7, at 13; Kreps, Research Needs and Policy Issues on Mass Media Disaster Reporting, 1980 COMMITTEE ON DISASTERS AND THE MASS MEDIA WORKSHOP 35.

18. Rumors of a bank's insolvency, for example, can become self-fulfilling prophecies if a signifcant number of people react by withdrawing their deposits, as occurred during the Depression. $R$. HOFSTADTER, W. MILLER \& D. AARON, THE UNITED STATES: THE HISTORY OF A REPUBLIC 715 (2d ed. 1967). A person now commits a federal misdemeanor if he

... willfully and knowingly makes, circulates, or transmits to another or others any statement or rumor, written, printed or by word of mouth, which is untrue in fact and is directly or by inference derogatory to the financial condition or affects the solvency or financial standing of the Federal Savings and Loan Insurance Corporation ....

18 U.S.C. $\S 1009$ (1976); see also N.Y. Stock Exchange Rule 435(5), 2 N.Y.S.E. GUIDE (CCH) I 2435 (forbidding circulation of sensational rumors that might reasonably be expected to affect market conditions on Exchange); Am. Stock Exchange Rule 3(c), 2 AM. STOCK EX. GUIDE (CCH) II 9223, at 2417 (same). But see Wall St. J., Feb. 6, 1979, at 1, col. 1 (N.Y.S.E. rule rarely invoked because of difficulties in determining who starts or spreads rumors). Not all institutions, of course, can claim the need for such protection from rumor. See Barrett v. Thomas, 649 F.2d 1193 (5th Cir. 1981) (upholding lower court decision striking down for overbreadth sheriffs office regulation prohibiting "gossiping" about department members or affairs).

19. A reputation for accuracy is essential if a reporter is to convince reluctant sources that he can be trusted with sensitive information. In addition, a reporter or newspaper that abuses its use of unorthodox sources will lose the trust of its readers.

20. The identification within a story of the source of information is termed an "attribution." Attributed information is a large part of reported news. See B. ROSHCO, NEWSMAKING 63 (1975) (while attendance at newsworthy events is preferred, most news is gathered through informants); see also Time, Inc. v. Pape, 401 U.S. 279, 285 (1971) ("[A] vast amount of what is published in the daily and periodical press purports to be descriptive of what somebody said rather than of what anybody did.").

21. See J. HOHENBERG, supra note 8, at 104. 
story's truth and thereby its newsworthiness. Including the source in the story is the most effective way of communicating that judgment to the reader. For example, a reader is more likely to believe a report of an impending epidemic if it is issued by a government health agency than if it is gleaned from a rumor mill.

An attribution, however, can do more than lend credence to newsworthy information; the attribution may be newsworthy itself. Just as an attribution may reveal something about the veracity of the report, the report may reveal something about the source to which the report is attributed. Mudslinging during a political campaign is an obvious example of this second function of attribution. The charges by themselves would not be newsworthy if they were known to be false, since they would tell the reader nothing of value about the person being attacked. But the publication of the statement, coupled with its source, provides the reader with valuable information about the candidate making the charge, the campaign, and campaigning in general. ${ }^{22}$ Similarly, the fact that a rumor is circulating among a certain group reveals information about the group-the pressures being brought to bear on this group and how the group may respond. In the extreme case, trivial or even false information may be newsworthy because of the way it reflects on who said it or where it was said. ${ }^{23}$

The effectiveness of an attribution in either of these roles depends upon the specificity with which the source is described. While the label rumor itself is effective in conveying information to the reader, specificity in describing the group within which a rumor is circulating can increase the attribution's value. The reader's evaluation of the rumor may differ depending upon the education, position, and influence of those spreading the rumor.

22. Note, however, that the value of the statement can be communicated to the reader only if he is informed of the statement's falsity.

23. The press coverage of the President provides a case in point. As a press secretary to President Lyndon B. Johnson wrote:

There is no other official of the government who can make a top headline story merely by releasing a routine list of his daily activities. There is no other official of the government who can be certain of universal newspaper play by merely releasing a picture of a quiet dinner with boyhood friends. There is no other official who can attract public attention merely by granting an interview consisting of reflections, no matter how banal or mundane, on social trends in fields where he has no expertise and in which his concepts are totally irrelevant to his function as a public servant.

G. REEDY, THE TWILIGHT OF THE PRESIDENCY 101 (1970).

While this second function of attribution no doubt helps the President by keeping him in the public cye, it can hurt him, too. Through both the style and substance of their answers at press conferences, Presidents Harry S Truman and Dwight D. Eisenhower created images in the minds of the public: for Truman, one of arrogance and obstinacy; for Eisenhower, one of irresolution. See D. CATER, THE FOURTH BRANCH OF GOVERNMENT 42 (1959). 


\section{Libel Law, Rumor, and Republished Speech}

Under traditional common-law doctrine, the publisher of a defamatory rumor incurred a high risk of liability. Following the constitutionalization of much of libel law in New York Times Co. v. Sullivan ${ }^{24}$ and Gertz v. Robert Welch, Inc., ${ }^{25}$ the risk was lessened but is still considerable. The new rules of libel are more generous than those they replaced, but they still fail to provide adequate protection to the publisher of rumor.

\section{A. Common-Law Libel and Rumor Before Sullivan}

Before 1964, the publication of defamatory rumor would in most cases provide the basis for a successful libel suit. The common-law claim of libel was easy to establish; many jurisdictions required only a showing of the defamatory nature ${ }^{28}$ of the material and the fact of its publication. ${ }^{27}$ If the publisher was not protected by a privilege, ${ }^{28}$ his only defense in many jurisdictions was to prove the truth of his publication. ${ }^{29}$ This was a diffi-

24. 376 U.S. 254 (1964).

26. A defamatory communication typically is defined as one that tends to hold the plaintiff up to hatred, contempt, or ridicule, to cause him to be shunned or avoided, or, more generally, as one that injures reputation. See Brown v. News-World Publishing Corp., 245 So. 2d 430, 432 (La. Ct. App. 1971); Stone v. Essex County Newspapers, Inc., 367 Mass. 849, 853, 330 N.E.2d 161, 165 (1975); RESTATEMENT (SECOND) OF TORTS § 559 (1976).

27. Holden v. American News Co., 52 F. Supp. 24 (E.D. Wash. 1943), appeal dismissed, 144 F.2d 249 (9th Cir. 1944); Ripps v. Herrington, 241 Ala. 209, 212, 1 So. 2d 899, 902 (1941); RESTATEMENT OF TORTS $\$ 558$ (1938).

28. As an alternative to the defense of truth, both the pre- and post-Sullivan publishers of rumor could raise the defense of conditional privilege. In its most common form, the conditional privilege protects any fair and accurate report of defamatory statements made in connection with the operation of government. See infra note 62. Outside of the governmental context, the common law recognizes a privilege to report rumor, even if known to be false, if legal duty or social obligation requires such action. See, e.g., Hogan v. New York Tímes Co., 211 F. Supp 99, 111 n.24 (D. Conn. 1962) (dictum) (suggesting that publication of rumor by newspaper would be protected by privilege to publish rumor in limited circumstances), affd, 313 F.2d 354 (2d Cir. 1963); Stukuls v. State, 42 N.Y.2d 272, 27883,366 N.E.2d 829, 833-35, 397 N.Y.S.2d 740, 744-46 (1977) (applying conditional privilege to report of rumor in defamation action between employer and employee); RESTATEMENT (SECOND) OF TORTS $\S 602$ (1976) (recognizing privilege for publishing defamatory rumor). Cf. Bocchicchio v. Curtis Publishing Co., 203 F. Supp. 403, 412 (E.D. Pa. 1962) (upholding jury charge that "a publisher may have a privilege to publish, for a relatively large segment of the public, material which an individual, who is not a publisher, may not have a privilege to say because no public policy would justify such individual gossip"). But cf. Lundin v. Post Publishing Co., 217 Mass. 213, 215, 104 N.E. 480, 481 (1914) (newspaper publishers have no greater rights to give currency to false charges than other persons).

29. See, e.g., Holden v. American News Co., 52 F. Supp. 24, 32 (E.D. Wash. 1943), appeal dismissed, 144 F.2d 249 (9th Cir. 1944); Ripps v. Herrington, 214 Ala. 209, 212, 1 So. 2d 899, 902 (1941); W. PROSSER, HANDBOOK OF THE LAW OF TORTS § 116, at 796-99 (1971). The common law did not allow a publisher to advance the defense that reasonable care had been used in preparing the report. The rules governing libel were, in effect, those of strict liability. Peck v. Tribune Co., 214 U.S. 185, 189 (1909); Sorensen v. Wood, 123 Neb. 348, 356-57, 243 N.W. 82, 86 (1932), appeal dismissed sub nom. KFAB Broadcasting Co. v. Sorensen, 290 U.S. 599 (1933) (per curiam). But see New York Times Co. v. Sullivan, 376 U.S. 254, 280 n.20 (1964) (listing states with standards of liability more lenient toward publisher). 
cult burden to bear in suits based on news stories using standard sources; ${ }^{30}$ it was often impossible when the report was drawn from rumor, since the essential characteristic of a rumor is its uncertain factual basis.

Given these rules, a publisher might have been tempted to ease his burden of proof by explicitly attributing the defamatory information in the news story to rumor. Logically, the publisher could then advance a successful defense merely by proving that the rumor existed, rather than by proving that the rumor was true. But the common law barred the libel defendant from using this strategy by holding that the publisher of a defamatory statement adopted the statement as his own and incurred the same liability as if he were the original speaker. ${ }^{31}$ Even if the publisher included in his report information contradicting the rumor, the law held him liable. ${ }^{32}$

\section{B. Rumor and the Sullivan-Gertz Standard}

Much of the common law of libel has been supplanted by the line of Supreme Court cases that began with New York Times Co. v. Sullivan, ${ }^{33}$ a libel action brought by the police commissioner of Montgomery, Alabama. ${ }^{34}$ In Sullivan, the Court identified the core of speech protected by the First Amendment as expression upon public issues. ${ }^{35}$ In addition, the

30. The burden was heavy because courts at one time required defendants to prove that their defamatory publications were literally true. See W. PROSSER, supra note $29, \$ 116$, at 798 . Modern decisions require that defendants show that the defamatory material is substantially true. Emde v. San Joaquin County Cent. Labor Council, 23 Cal. 2d 146, 160, 143 P.2d 20, 28 (1943); Kilian v. Doubleday \& Co., 367 Pa. 117, 123, 79 A.2d 657, 660 (1951); W. PROSSER, supra note 29, § 116, at 798.

31. See Dun \& Bradstreet, Inc. v. Robinson, 233 Ark. 168, 172-73, 345 S.W.2d 34, 37 (1961) (defendant must prove truth of substance of rumor even though report included disclaimer "it is currently reported"); Cobbs v. Chicago Defender, 308 Ill. App. 55, 59, 31 N.E.2d 323, 325 (1941) (attribution to rumor does not relieve publisher of liability for report); RESTATEMENT OF TORTS $\S$ 578 (1938) (republisher of defamatory statement subject to liability as if had originally published statement); cf. Hope v. Hearst Consol. Publications, 294 F.2d 681 (2d Cir. 1961) (upholding jury award in libel suit based on gossip column item that began "Palm Beach is buzzing with the story . . . "), cert. denied, 368 U.S. 956 (1962); Thackrey v. Patterson, 157 F.2d 614 (D.C. Cir. 1946) (reversing dismissal of complaint in libel suit based on article reporting "conjectures" and "saucy little rumors" about plaintiffs). The attribution could be cited as a factor toward mitigating damages, however. See Bishop v. Journal Newspaper Co., 168 Mass. 327, 47 N.E. 119 (1897). The common law put the publisher in the shoes of the original speaker because of the substantial additional injury caused by the publication. See Venn v. Tennessean Newspapers, Inc., 201 F. Supp. 47, 57 (M.D. Tenn. 1962), affd mem., 313 F.2d 639 (6th Cir.), cert. denied, 374 U.S. 830 (1963).

32. See Bishop v. Journal Newspaper Co., 168 Mass. 327, 47 N.E. 119 (1897); RESTATEMENT (SECOND) OF TORTS, § 548 comment e (1976).

33. 376 U.S. 254 (1964).

34. The commissioner's suit was based on an advertisement in the New York Times criticizing the treatment of Southern civil rights activists. The Supreme Court overturned a $\$ 500,000$ judgment awarded by an Alabama jury to the commissioner. 376 U.S. at 256.

35. 376 U.S. at 269. At another point, the Court rephrased this principle by stating that "debate on public issues should be uninhibited, robust, and wide-open." Id. at 270 . The Court repeatedly emphasized the importance to the democratic process that no individual be restrained from adding his voice to the public debate. The importance of such freedom of access is based on the assumption that 
Court considered the strategic question of where the specific line of protection around this core speech should be drawn.$^{36}$ It concluded that beneficial debate on public issues would reach its optimal level if freedom from liability were widened to embrace not only statements that could be proven true but also "erroneous statements honestly made."37 To achieve what it decided was an appropriate level of protection, the Court established the "actual malice"s8 test of liability. Under that test, a public official could recover in a libel action only if he showed that "the [defamatory] statement was made . . . with knowledge that it was false or with reckless disregard of whether it was false or not."38

The decision in Sullivan used as its starting point the issue of seditious libel..$^{40}$ In the cases following Sullivan, as the Court debated how much more broadly actual malice protection should sweep, the argument was recast more generally as one weighing the state's interest in compensating

the democratic process will reach proper results only if rival ideas are allowed to compete. Id. In addition, such access allows the individual to participate fully in the democratic process, thereby promoting his sense of fulfillment and worth. It is assumed that government will be more stable in such a system. Id. at 269-70; see also Meiklejohn, The First Amendment is an Absolute, 1961 SUP. Cr. REV. 245, 255 (First Amendment protects activities of thought and communication by which citizens "govern"); Brennan, The Supreme Court and the Meiklejohn Interpretation of the First Amendment, 79 HARV. L. REV. 1 (1965) (discussing relevance of Meiklejohn theory to Sullivan analysis); Kalven, The New York Times Case: A Note on "The Central Meaning of the First Amendment," 1964 SUP. CT. REV. 191, 207-13, 221 (same).

36. The Court held that Alabama's libel law drew the line around permissible public debate too tightly. By allowing a public official to establish libel through a simple showing of defamatory effect, the Alabama law failed to acknowledge that the hallmark of effective criticism is in fact its impact in injuring an official's reputation. By providing the defendant newspaper with only the defense of truth, the law failed to recognize the inevitability of factual error in free debate. 376 U.S. at 271-73.

37. Id. at 278. This analysis usually is summarized as an attempt to see if the rule of liability creates adequate "breathing space" "for the desired speech. Id. at 272 (quoting NAACP v. Button, 371 U.S. $415,433(1963)$ ). While the major contribution to public debate comes from a speaker who speaks the truth, the Court was willing to protect some false speech so that criticism believed to be true and in fact true might not be discouraged by fear of liability. The Court's interest in protecting false speech lay only in its value as a buffer for true speech. Id. at 279. False speech itself, whether intentional or careless, has been held to have no inherent constitutional value. Gertz v. Robert Welch, Inc., 418 U.S. 323, 340 (1974); St. Amant v. Thompson, 390 U.S. 727, 732 (1968).

38. "Actual malice" was an unfortunate choice of words, as it could potentially be confused with "malice" in common law libel, which means ill will or spite. See Gertz v. Robert Welch, Inc., 418 U.S. 323, 334, n.6 (1974); Beckley Newspapers Corp. v. Hanks, 389 U.S. 81 (1967) (per curiam).

39. 376 U.S. at 279-80. Reckless disregard was later explained to mean that the defendant must have "entertained serious doubts as to the truth of his publication." St. Amant v. Thompson, 390 U.S. 727,731 (1968). The Sullivan Court also rejected the preponderance of the evidence standard for libel cases; instead, the plaintiff had to show actual malice with "convincing clarity." 376 U.S. at 285-86.

Knowledge of falsity and the possession of serious doubts as to truth are both subjective standards based on the state of mind of the publisher. Obviously the defendant is best qualified to render evidence as to his own state of mind. But the defendant's profession of belief is not necessarily dispositive. Subsequent cases have focused on objective evidence that may prove or disprove the required state of mind. See St. Amant v. Thompson, 390 U.S. 727 (1968) (reviewing development of actual malice standard).

40. The Court asserted that the commitment to uninhibited debate on public issues recognized in Sullivan was initially formulated during the controversy over the Sedition Act of 1798. 376 U.S. at 273. At its narrowest, Sullivan can be read as establishing the unconstitutionality of seditious libel laws. 
the victims of libel against the First Amendment interest in promoting the public debate." It was not until nine years after Sullivan that a stable

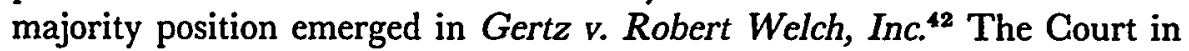
Gertz held that the status of the plaintiff was the critical factor in striking the appropriate balance. The Court asserted that plaintiffs who are public officials or public figures ${ }^{43}$ have access to the media and can mitigate the defamation's effect through their own efforts, and that they assume a greater risk of injury from defamation through their involvement in public life. Such plaintiffs, therefore, need only the limited protection of actual malice. Private individuals, in contrast, have little opportunity for selfhelp and do not seek publicity; therefore, the Court held that requiring them to prove actual malice would unduly infringe upon the state's inter-

41. The first explicit disagreement over the relative weight to be given reputational interests occurred in Rosenblatt v. Baer, 383 U.S. 75 (1966). The plaintiff was the former supervisor of a county recreation area who claimed to have been libeled by a newspaper column criticizing his management of finances; at issue was whether he fell within the Sullivan definition of public official. The majority noted that there was a strong interest in debate on "public issues" and in debate about those persons in a position to influence the resolution of those issues. This interest overcame society's "pervasive and strong interest in preventing and redressing attacks upon reputation." The Court therefore held that the actual malice standard applied. Id. at 85-86. In a concurring opinion, Justice Stewart urged a much narrower approach, arguing that constitutional libel law should continue to focus on seditious libel. Id. at 91-92 (Stewart, J., concurring).

Justice Harlan took up the idea that actual malice should be limited to seditious libel cases in Curtis Publishing Co. v. Butts, 388 U.S. 130 (1967). Harlan asserted that the interest in reputation of a private individual who was prominent or involved in the public debate dictated a negligence standard of liability that, though demanding, fell below the rigor of actual malice. Id. at 154-55. Chief Justice Warren, in a concurring opinion that is treated as controlling, rejected Harlan's negligence test as an "unusual and uncertain formulation" and stated that public figures must show actual malice. $I d$. at 163-64 (Warren, C.J., concurring). A plurality in Rosenbloom v. Metromedia, Inc., 403 U.S. 29 (1971) then shifted the focus of actual malice protection from the status of the plaintiff to the subject matter at issue. Actual malice was held to apply to any libel action involving an event of public or general concern. The plurality noted the "important interests" of an individual's public reputation and good name that are protected by state libel law but held that they were outweighed by the needs of freedom of the press and speech. Id. at 49-50. The dissenters attacked the plurality position for insufficiently protecting individuals who had not voluntarily placed themselves in the public light and for creating a judicially unmanageable standard of liability. Id. at 62 (Harlan, J., dissenting); id. at 78 (Marshall, J., dissenting). The dissenters' position prevailed three years later, when the Court returned the focus of libel law to the plaintiff's status in Gertz v. Robert Welch, Inc., 418 U.S. 323 (1974).

42. 418 U.S. 323 (1974).

43. Gertz hypothesized two types of public figures: an individual who is so well-known that he becomes a "public figure for all purposes" and an individual who is a "public figure for a limited range of issues." The latter type is further divided into two categories: the individual who voluntarily injects himself into a public controversy and the individual who is involuntarily drawn into such a controversy. Id. at 351.

Cases following Gertz have retained the Gertz dichotomy but have narrowed the classes of plaintiffs who might qualify as public figures. Several factors may be isolated in the more recent Supreme Court libel decisions, most or all of which must be present in order to establish that the plaintiff is a public figure: the existence of a public controversy, see Hutchinson v. Proxmire, 443 U.S. 111, 135 (1979); Time, Inc. v. Firestone, 424 U.S. 448, $453-54$ (1976); the plaintiff's voluntary self-injection into that controversy, see Wolston v. Reader's Digest Ass'n, 443 U.S. 157, 166 (1979); Firestone, 424 U.S. at 454; the extensiveness of plaintiffs participation in the controversy, see Wolston, 443 U.S. at 168; Hutchinson, 443 U.S. at 135-36; and the plaintiffs access to the media, see Hutchinson, 443 U.S. at 136 . 
est in compensating them for the harm inflicted by defamatory falsehood. The Court, however, did not believe that the state interest completely overrode First Amendment considerations in suits involving private figures; it also held that the states could not impose liability without a showing of fault on the part of the publisher. ${ }^{44}$

Yet even following Sullivan and Gertz, the publisher of rumor faced a serious threat of liability. In suits brought by private individuals, the publication of defamatory rumor would be actionable under the Gertz fault requirement, since injury arising from such a publication would almost certainly be held to be a result of negligence. ${ }^{45}$ Nor would this result change if the report were explicitly attributed to rumor. At first glance, the addition of the attribution would seem to change the content of the message being communicated and therefore would alter the factors weighed in the negligence calculus. Many courts, however, have taken the position in private-figure cases that the common-law rule holding the publisher liable as if he were the original speaker survived Gertz. These courts would judge liability by the same negligence standard that would apply if the rumor were reported as fact, ${ }^{48}$ although the qualifying attri-

44. Gertz, 418 U.S. at 347-50. The Court also ruled that punitive damages could not be recovered by private plaintiffs unless actual malice was shown. $I d$.

45. Following Gertz, many jurisdictions have adopted negligence as the standard of liability in libel cases brought by private persons. See, e.g., McCall v. Courier-Journal \& Louisville Times Co., 623 S.W.2d 882, 894 (Ky. 1981), cert. denied, 102 S. Ct. 2239 (1982); Memphis Publishing Co. v. Nichols, 569 S.W.2d 412 (Tenn. 1978); RESTATEMENT (SECOND) OF TORTS § 580B (1976). One method of gauging negligence in libel cases is to determine whether the defendant had reasonable grounds for believing that the communication was true. See Taskett v. King Broadcasting Co., 86 Wash. 2d 439, 445, 546 P.2d 81, 85 (1976); RESTATEMENT (SECOND) OF TORTS, $§ 580 B$ comment $g$ (1976). Since rumor by definition lacks a solid factual basis, the publisher who prints rumor with no substantiating information would probably be found to have acted unreasonably. Negligence also is judged according to the customs and practices of the profession. See Gobin v. Globe Publishing Co., 216 Kan. 223, 233, 531 P.2d 76, 84 (1975); RESTATEMENT (SECOND) OF TORTS $§ 580 B$ comment $g$ (1976). Journalists as a profession disapprove of printing rumors. The negligence standard also considers the interests the defendant was seeking to promote by publishing the defamatory matter. "Informing the public as to a matter of public concern is an important interest in a democracy; spreading of mere gossip is of less importance." RESTATEMENT (SECOND) OF TORTS $\$ 580 \mathrm{~B}$ comment $\mathrm{h}$ (1976).

46. The Tenth Circuit took this position in Dixson v. Newsweek, Inc., 562 F.2d 626 (10th Cir. 1977). Dixson, a former vice-president of Frontier Airlines, won a libel verdict against Newsweek based on a story that discussed his discharge from the financially troubled company. In affirming the verdict, the circuit court rejected Newsweek's defense that its story had accurately reported the statements of other Frontier executives. The court said the jury finding to the contrary was supported by the record and added that "[b]e that as it may, the republication of false defamatory statements is as much a tort as the original publication." Id. at 630-31. The court had earlier noted that Gertz forbade only strict liability in cases involving private individuals; "[w]ithin the stated limitations, a state is free to act." Id. at 629. Presumably, this freedom extends to negating the impact on liability of attributions. Other courts have reached the same conclusion. See Dresbach v. Doubleday \& Co., 8 MEDIA L. REP. (BNA) 1793, 1795 (D.D.C. 1982); Hoover v. Peerless Publications, Inc., 461 F. Supp. 1206, 1209 (E.D. Pa. 1978); McCall v. Courier-Journal \& Louisville Times Co., 623 S.W.2d 882, 894 (Ky. 1981) (Lukowsky, J., filing separately), cert. denied, 102 S. Ct. 2239 (1982); RESTATEMENT (SECOND) OF TORTS) $\$ 578$ (1976); cf. Moran v. Hearst Corp., 40 N.Y.2d 1071, 1072, 360 N.E.2d 932, 932, 392 N.Y.S.2d 253, 254 (1976) (Fuchsberg, J., concurring) ("Even granting defendants' contention that the article in question made clear that the statements being reported were only 'gos- 


\section{bution might help to mitigate damages. ${ }^{47}$}

In public-figure cases, there is the additional protection of the actual malice rule. But even if the publisher professed to have a good-faith belief in the truth of the rumor, the reporting of rumor as fact could still create liability. The defamed party might prove reckless disregard of the truth by showing that the publisher failed to investigate the rumor to establish its veracity. While the Court has held that actual malice is not measured by whether a reasonably prudent person would have investigated the truth of his publication, ${ }^{48}$ it has indicated that certain categories of sources are of such questionable reliability that a failure to investigate may provide grounds for finding actual malice.49

Explicitly labeling the report as rumor raises more complicated questions when liability is judged by the actual malice test. A news report based on attributed information contains two potential sources of falsity: in the report of what was said and in the original statement itself.

The issue of actual malice as it relates to the accuracy of quotations was addressed in a straightforward manner by the Supreme Court in Time, Inc. v. Pape. ${ }^{30}$ The implication of the ruling, not surprisingly, was that a publisher acts with actual malice if he knows that his account of a third party's statement is inaccurate. ${ }^{\text {s1 }}$

sip', the tone, style, and arrangement of the 'gossip' was such that the average reader might well be inclined to conclude that where there is smoke there is fire.").

47. See RESTATEMENT (SECOND) OF TORTS § 578 comment e (1976).

48. See Gertz v. Robert Welch, Inc., 418 U.S. 323, 332 (1974); St. Amant v. Thompson, 390 U.S. 727, 731 (1968); New York Times Co. v. Sullivan, 376 U.S. 254, 287-88 (1964).

49. Examples would be basing the story wholly on an unverified anonymous telephone call, reporting allegations so inherently improbable that only a reckless man would put them into circulation, and using material from an informant despite the existence of obvious reasons to doubt the informant's veracity or the accuracy of his reports. St. Amant v. Thompson, 390 U.S. 727, 732; see also Curtis Publishing Co. v. Butts, 388 U.S. 130, 157 (1967) (publisher knew that source of news story was on probation but did not investigate accuracy of source's statements); id. at 169 (Warren, C.J., concurring) (characterizing investigation of source's veracity as "slipshod and sketchy").

50. 401 U.S. 279 (1971). The case involved a libel claim against Time based on an article describing a report by the United States Commission on Civil Rights. The report at one point summarized allegations of police brutality made against Deputy Chief of Detectives Pape and other Chicago police officers. Time quoted the summary but did not indicate that the events described were allegations rather than commission findings. Pape filed suit, alleging not that the events described were false but that Time gave the allegations credibility by falsely presenting them as official findings. Since Time admitted it had consciously chosen to omit the word "alleged," thus satisfying the scienter requirement of actual malice, the question became whether the article was a falsification of the report. The Court held that given the ambiguity of the report, Time's interpretation might represent an error in judgment but did not constitute reckless disregard of the truth. Id. at 280-82, 285, 292; see also Greenbelt Coop. Publishing Ass'n v. Bresler, 398 U.S. 6, 12-13 (1970) (dictum) (accurate report of city council meeting did not constitute actual malice); Sowle, Defamation and the First Amendment: The Case for a Constitutional Privilege of Fair Report, 54 N.Y.U. L. REV. 469, 501-08 (1979) (describing plaintiff's and defendant's litigation strategies in Pape).

51. Some courts have read Pape as creating a privilege that would protect the publisher's accurate publication of another party's statements, even if the publisher knew the statements to be false. See, e.g., Edwards v. National Audubon Soc'y, 556 F.2d 113, 120 (2d Cir.), cert. denied, 434 U.S. 1002 (1977); Novel v. Garrison, 338 F. Supp. 977, 982-83 (N.D. Ill. 1971). This interpretation reads too 
The more interesting question is posed by the second source of falsity. The Supreme Court has not directly faced the issue of whether a publisher acts with actual malice by publishing statements that, while accurately attributed, he knows or suspects to be false. But two pre-Gertz ${ }^{\text {s2 }}$ opinions suggest that this may be the case. The first, St. Amant v. Thompson, ${ }^{63}$ involved a candidate for public office who, during a televised speech, read a statement made by a local union member that defamed the parish deputy sheriff. The sheriff sued the candidate for libel and won. The candidate claimed at trial and on appeal that, because his statements were quoted from another speaker, he could not be held responsible for their underlying falsity. The Supreme Court reversed the Louisiana court on the ground that there was insufficient evidence to show that the candidate acted with reckless disregard for the truth. But it did agree that the defendant's claim of immunity was unfounded, and it did not cite the attribution as a relevant factor in its finding of insufficient evidence. ${ }^{54}$

In the second case, Greenbelt Cooperative Publishing Association v. Bresler, ${ }^{\text {b5 }}$ the majority did not reach the attribution issue, but Justice White addressed it in his concurrence. The respondent in Greenbelt was a local real estate developer and builder whose offer to sell land to the city in return for certain zoning variances had been characterized as "blackmail" at several city council meetings. The local newspaper reported the controversy, including the blackmail charges. The developer sued the newspaper for libel, claiming that the report charged him with committing a crime, and won. The Supreme Court reversed the decision, holding that the charge of blackmail, when viewed in the context of the city council meeting, was rhetorical hyperbole, not an accusation of criminal conduct, and therefore was not libelous. ${ }^{83}$ But Justice White's concurrence noted that if the charge had been libelous, the newspaper, which admitted it knew such an accusation to be false, would have published with actual malice. ${ }^{.87}$

much into Pape, however, since the accuracy of the Commission's report was not at issue. See Cianci v. New Times Publishing Co., 639 F.2d 54, 67 n.15 (2d Cir. 1980); Sowle, supra note 50, at 501-08.

52. The Gertz reformulation of libel law does not alter the inferences to be drawn from these cases. The issue in Gertz was the breadth with which the actual malice standard should be applied; the elements of the test itself were left unchanged.

53. 390 U.S. 727 (1968). Sullivan also implicitly raised the issue of republished speech, since the basis of the suit was an advertisement.

54. Id. at $730-33$.

55. 398 U.S. 6 (1970).

56. Id. at 14.

57. Id. at 23 (White, J., concurring). Justice White's analysis was based upon whether the newspaper's report could be interpreted as charging the plaintiff with the commission of a crime. The Court had found, however, that the report was an accurate account of the events at the meeting. Id. at 12-13. Thus, Justice White would have held the newspaper liable, even though its report was accurate. Other courts support Justice White's approach in applying actual malice. See, e.g., Cianci v. New Times Publishing Co., 639 F.2d 54, 60-61 (2d Cir. 1980) (publisher incurs liability under 
The conclusion to be drawn from the cases is that a newspaper that publishes defamatory rumor, or any third party's defamatory statement that the publisher knew or should have known to be false, incurs a serious risk of liability. ${ }^{58}$ Courts have reached this strict result by adopting a view of actual malice that focuses only on the falsity of the defamatory statement itself and ignores the inclusion of an attribution and other information revealing the statement's questionable validity. This narrow approach makes sense when the only purpose of the attribution is to communicate the truth of the statement being reported. The statement's value to the reader rests upon its truth, and if the publisher knows or should suspect that the statement is false, he should be discouraged from publishing it. The courts effectively achieve this result by holding that the publisher adopts the original speaker's statement as his own and therefore is liable if he is aware of the statement's falsity. A narrow approach is inadequate, however, when the attribution to rumor reveals something about the character of the source or the event from which it arises. ${ }^{59}$ In these cases, the falsity of the material does not destroy the report's value but only affects the message the report conveys. By putting the publisher in the original speaker's shoes, the actual malice test discourages him from reporting this valuable but false speech and thus prevents him from presenting a full account of newsworthy events.

actual malice standard if he knew of falsity, regardless of attribution); Dickey v. CBS Inc., 583 F.2d 1221, 1226 (3d Cir. 1978) (rejecting argument that "false statements by a third party which have been published by the press, are entitled to a unique constitutional analysis"); Edwards v. National Audubon Soc'y, 556 F.2d 113, 119 (2d Cir.) (newspaper reporter could be found to have acted with actual malice if he had serious doubts about truth of defamatory allegations, even if he did not have any doubts that he was reporting them faithfully), cert. denied, 434 U.S. 1002 (1977); Goldwater v. Ginzburg, 414 F.2d 324, 337 (2d Cir. 1969) (repetition of another's words does not release one of responsibility if repeater knows that words are false, inherently improbable, or there are obvious reasons to doubt veracity of person quoted or accuracy of his reports) (citing St. Amant v. Thompson, 390 U.S. 727, 732 (1968)), cert. denied, 396 U.S. 1049 (1970); Catalano v. Pechous, 83 Ill. 2d 146, 168, 419 N.E.2d 350, 361 (1980), cert. denied, 451 U.S. 911 (1981). Other courts have been reluctant to apply actual malice strictly in cases involving the publication of defamatory statements originating with other speakers. See Medina v. Time, Inc., 439 F.2d 1129, 1130 (1st Cir. 1971); Oliver v. Village Voice, Inc., 417 F. Supp. 235, 238 (S.D.N.Y. 1976); Novel v. Garrison, 338 F. Supp. 977, 982-83 (N.D. III. 1971).

Not only did the newspaper article in Greenbelt accurately report the statements made at the council meeting, it also presented both sides of the discussion. Thus, Justice White's position is particularly unsettling in light of the evenhanded treatment given the controversy. $C$. Airlie Found. v. Evening Star Newspaper Co., 337 F. Supp. 421 (D.D.C. 1972) (upholding jury finding of knowing or reckless falsity despitc publication of denials).

58. An empirical study of libel cases has shown that the press loses a greater percentage of libel suits when it reports the public comments of others than when it reports its own stories. Franklin, Winners and Losers and Why: A Study of Defamation Litigation, 1980 AM. B. FOUND. RESEARCH J. 457, 489.

59. See supra p. 89; cf. Robertson, Defamation and the First Amendment: In Praise of Gertz v. Robert Welch, Inc., 54 TEX. L. REV. 199, 266 (1976) (where making of charge is newsworthy event, newpaper that publishes charge with source should not be interpreted as impliedly supporting veracity of charge). 
III. Rumor and the Constitutional Privilege to Report the Statements of Others

The special treatment required by republished speech has been addressed by the Second Circuit, which in Edwards v. National Audubon Society $^{60}$ adopted a constitutional privilege protecting such publications in limited circumstances. Any attempt to devise a libel standard for rumor should begin with $E d w a r d s$. While $E d w a r d s$ represents a significant step toward resolving the shortcomings of the Sullivan-Gertz line of cases, its scope is too narrow, and it is not designed to address the special concerns raised by reports based on rumor and other unorthodox sources. The Note discusses how the privilege could be modified to do so.

\section{A. Establishing the Republication Privilege}

The Second Circuit, recognizing the value of republishing certain false speech, created in $E d w a r d s$ a constitutional privilege to publish another's statements "regardless of the reporter's private views regarding their validity." "61 A jury had found the New York Times guilty of libel after it printed allegations by the National Audubon Society that five scientists who supported the continued use of the pesticide DDT were "paid liars" for the pesticide industry. The Second Circuit reversed the verdict against the Times, holding that the plaintiffs had not established actual malice, and that, even if actual malice had been shown, the reporter would have possessed a constitutional privilege to publish the charges. ${ }^{62}$ The privilege,

60. 556 F.2d 113 (2d Cir.), cert. denied, 434 U.S. 1002 (1977).

61. Id. at 120. Edwards has been discussed in Sowle, supra note 50, at 527-28; Note, Protecting the Public Debate: A Proposed Constitutional Privilege of Accurate Republication, 58 TEX. L. REV. 623, 638-40 (1980); Comment, Constitutional Privilege to Republish Defamation, 77 CoLUM. L. REV. 1266 (1977); Comment, Restricting the First Amendment Right to Republish Defamatory Statements, 69 GEO. L.J. 1495 (1981); Comment, Edwards v. Nat'l Audubon Soc'y, Inc.: The Right to Print Known Falsehoods, 1979 U. ILL. L.F. 943; Comment, The Privilege of Neutral Reportage-Edwards v. National Audubon Society, Inc., 1978 UTAH L. REV. 349.

62. 556 F.2d at 120 . The court called this privilege the "right of neutral reportage." Id. The Edwards constitutional privilege finds its roots in the common-law privileges of republication. These privileges constitute an important set of exceptions to the common-law rule that the republisher of a defamatory statement incurs the same liability as if he had originated the statement. See supra p. 91. The privileges primarily cover the reporting of statements made in connection with the operation of government. If the report of a statement falls within the privilege, the publisher cannot be held liable if the report was a fair and accurate account of what occurred. See Medico v. Time, Inc., 509 F. Supp. 268, 272 (E.D. Pa. 1980), aff', 643 F.2d 134 (3d Cir.), cert. denied, 454 U.S. 836 (1981); RESTATEMENT (SECOND) OF TORTS $\$ 611$ (1976). The common-law privileges may protect the publisher even if he knows that the statement is false. See, e.g., Hurley v. Northwest Publications, Inc., 273 F. Supp. 967, 975 (D. Minn. 1967), affd, 398 F.2d 346 (8th Cir. 1968); RESTATEMENT (SECOND) OF TORTS $\S 611$ comment a (1976). They may be lost, however, if the plaintiff shows that the publication was motivated by malice, that is, ill will or spite. See American Dist. Tel. Co. v. Brink's Inc., 380 F.2d 131, 133 (7th Cir. 1967); Langford v. Vanderbilt Univ., 199 Tenn. 389, 399, 287 S.W.2d 32, 37 (1956), remanded, 44 Tenn. App. 694, 318 S.W.2d 568, cert. denied, 44 Tenn. App. 694, 318 S.W.2d 568 (Tenn. 1958). But see Hill, Defamation and Privacy Under the First Amendment, 76 COLUM. L. REV. 1205, 1249 (1976) (forfeiture of privilege based on ill will may be 
as described by the court, would protect the "accurate and disinterested" reporting of "newsworthy" charges made by "responsible, prominent" speakers against public officials or public figures. ${ }^{63}$ If these criteria are not met, then liability would be determined under the Sullivan actual malice rule, and the publisher would be held responsible for knowledge of the underlying truth or falsity of the defamatory charge.

At first glance, the Edwards standard, because it extends the media's freedom from liability beyond Gertz, would seem to upset the constitutional balance struck by the Supreme Court between promotion of public debate and the state's interest in protecting reputation. ${ }^{64}$ But the publication of newsworthy statements of others, even though known to be false, enhances the public debate in a manner that was not the focus of the Sullivan-Gertz line of cases. ${ }^{65}$ Therefore, it could be argued that this tradeoff between promotion of debate and protection of reputation is not foreclosed by Gertz and may still fall within a constitutionally covered range. ${ }^{68}$ Such an argument is strengthened by the limitations imposed by

unconstitutional).

For a discussion of three theoretical bases used by courts to support the common-law privileges of republication, see Note, Privilege to Republish Defamation, 64 CoLUM. L. REv. 1102, 1103-16 (1964) (identifying "supervisory," "informational," and "agency" rationales).

63. Edwards, 556 F.2d at 120.

64. Cf. Time, Inc. v. Firestone, 424 U.S. 448, $455-57$ (1976) (extending actual malice protection to all reports of judicial proceedings would upset balance struck in Ger(z).

65. The Sullivan-Gertz line of cases based its reasoning on a democracy's need for strong debate on public issues and on a concern over the ability of the individual to add his voice to that debate. The issue in Edwards was different; there, the newspaper was not adding its voice to the debate but raiher was informing the public about how the debate was proceeding.

66. The Edwards court maintained that the role of the press in circulating newsworthy statements made by other speakers was constitutionally protected, citing Time, Inc. v. Pape, 401 U.S. 279 (1971), as a source of this constitutional privilege. 556 F.2d at 115, 120,122. This is a misreading of Pape, however. See Cianci v. New Times Publishing Co., 639 F.2d 54, 67 \& n.15 (2d Cir. 1980); supra note 50. $\Lambda$ betler source is New York Times v. Sullivan, 376 U.S. 254 (1964). Sullivan identifies the need to promote debate on public issues as the core of the First Amendment. Edwards correctly notes that by circulating newsworthy statements, the press enhances the individual's ability to participate intelligently in that debate. 556 F.2d at 115. ("It is elementary that a democracy cannot long survive unless the people are provided the information needed to form judgments on issues that affect their ability to intelligently govern themselves."). Other Supreme Court cases also indicate that the need to protecl speech performing this informational function may have constitutional dimensions. See Landmark Communications, Inc. v. Virginia, 435 U.S. 829 (1978) (striking down statute imposing criminal sanctions on publication of truthiful information about confidential proceedings of judicial commission); Nebraska Press $\Lambda$ ss'n v. Stuart, 427 U.S. 539, 560 (1976) ("The press does not simply publish information about trials but guards against the miscarriage of justice by subjecting the . . . judicial processes to extensive public scrutiny . . . .") (citing Sheppard v. Maxwell, 384 U.S. 333, 350 (1966)); Cox Broadcasting Corp. v. Cohn, 420 U.S. 469 (1975) (striking down statute imposing liability for invasion of privacy based on publication of truthful information obtained from court documents); Greenbelt Coop. Publishing Ass'n v. Bresler, 398 U.S. 6, 11 (1970) ("This case involves newspaper reports of public meetings of the citizens of a community concerned with matters of local governmental interest and importance. The very subject matter of the news reports, therefore, is one of particular First Amendment concern."); Hill, supra note 62, at 1219-20; Sowle, supra note 50, at 495-500. But cf. Time, Inc. v. Firestone, 424 U.S. 448, 455 (1976) (rejecting extension of actual malice protection to reports of judicial proceedings). The Supreme Court has not recognized a constitutional republication privilege covering suits for defamation, however, and its discussion of the consti- 
the elements of the $E d w a r d s$ test. ${ }^{67}$ The restriction of the privilege to suits brought by public officials and public figures ${ }^{\mathbf{8 B}}$ incorporates the recognition in Gertz that the plaintiff's status is a critical factor in balancing the

tutional value of the press's informational role has been limited to the context of governmental proceedings.

67. Given its recognition of the public-private plaintiff distinction, it is puzzling why Edwards stressed newsworthiness as a limitation on the privilege. The newsworthiness standard seems superfluous, since any charge leveled against a public official or public figure by a responsible, prominent speaker would be newsworthy. In a subsequent case, the Second Circuit indicated that the Edwards privilege would protect the accurate reporting of any newsworthy statement, regardless of the status of the defamed party or of the speaker. Herbert v. Lando, 568 F.2d 974, 980 (2d Cir. 1977) (dictum), rev'd on other grounds, 441 U.S. 153 (1979). But the court reaffirmed the original Edwards formula in Cianci v. New Times Publishing Co., 639 F.2d 54, 68-69 \& n.17 (2d Cir. 1980). But cf. Comment, Restricting the First Amendment Right to Republish Defamatory Statements, supra note 61, at 150107 (criticizing Cianci's reading of Edwards).

A rationale that might give the newsworthiness standard some meaning could be based on the dual functions of attribution. An attribution may lend credence to newsworthy information, or it may be newsworthy itself. See supra pp. 88-89, 97. If the newsworthiness standard is meant to protect only publications falling into the latter category, it is conceptually defensible. But from a practical point of view, such a distinction would be difficult to draw, and the resulting ambiguity might discourage publishers, uncertain as to how a particular attributed statement would be labeled, from publishing it. Cf. New York Times Co. v. Sullivan, 376 U.S. 254 (1964) (acknowledging strategic concerns in protection of speech); BeVier, The First Amendment and Political Speech: An Inquiry Into the Substance and Limits of Principle, 30 STAN. L. REV. 299, 347-52 (1978) (applying theory of strategic protection of speech to Supreme Court's defamation decisions).

Several courts that have followed or discussed Edwards have recognized newsworthiness and accuracy as the only limitations on the privilege. See, e.g., Whitaker v. Denver Post, Inc., 4 Media $\mathrm{L}$. Rep. (BNA) 1351 (D. Wyo. 1978); Hatjioannou v. Tribune Co., 8 MEDIA L. REP. (BNA) 2637 (Fla. Cir. Ct. 1982); Smith v. Taylor County Publishing Co., 8 MEdIA L. REP. (BNA) 1294 (Fla. Cir. Ct. 1982), appeal docketed, No. AN103 (Fla. 1st Dist. Ct. App. June 28, 1982); Krauss v. Champaign News Gazette, Inc., 59 Ill. App. 3d 745, 375 N.E.2d 1362 (1978); Campo Lindo for Dogs, Inc. v. New York Post Corp., 65 A.D.2d 650, 409 N.Y.S.2d 453 (1978); Orr v. Lynch, 60 A.D.2d 949, 401 N.Y.S.2d 897, affd, 45 N.Y.2d 903, 383 N.E.2d 562, 411 N.Y.S.2d 10 (1978); Belton v. Braham, 6 Media L. Rep. (BNA) 1787 (N.Y. Sup. Ct. 1980). Several courts that have rejected the contention that the Edwards rule is constitutionally mandated have done so on the grounds that a standard based on newsworthiness is inconsistent with the Supreme Court's decision in Gertz overturning the Rosenbloom newsworthiness test. See, e.g., Dickey v. CBS, 583 F.2d 1221, 1225-26 \& n.5 (3d Cir. 1978) (Edwards inconsistent with Gertz and St. Amant); Newell v. Field Enterprises, Inc., 91 Ill. App. 3d 735, 757, 415 N.E.2d 434, 451-52 (1980); McCall v. Courier-Journal \& Louisville Times Co., 623 S.W.2d 882, 886 (Ky. 1981), cert. denied, 102 S. Ct. 2239 (1982); Hogan v. Herald Co., 84 A.D.2d $470,478,446$ N.Y.S.2d 836, 842, affd, 58 N.Y.2d 630, 444 N.E.2d 1002, 458 N.Y.S.2d 538 (1982); see also Sowle, supra note 50, at 532 (privilege of republication covering statements "of legitimate public concern" inconsistent with Gertz). While Gertz is not entirely on point, since the constitutional value of republished speech differs from that of original speech, see note 65, a neutral reporting privilege that protects the republication of any newsworthy statement would fall far beyond the balance set out in Gertz between protected speech and reputation. See Gertz v. Robert Welch, Inc., 418 U.S. 323, 346 (1974) (newsworthiness standard provides too little protection to private individuals and is ill-suited for judicial application). This conclusion cannot be as easily drawn, however, if the privilege is further limited by other standards.

68. Some courts have dropped the public-private plaintiff distinction while retaining the other elements of the Edwards test, particularly the requirement that the defamatory statement be made by a responsible, prominent speaker. See Bair v. Palm Beach Newspapers, Inc., 8 MEDIA L. REP. (BNA) 2028 (Fla. Cir. Ct. 1982), appeal docketed, No. 82-1362 (Fla. Dist. Ct. App. June 29, 1982); Village of Grafton v. American Broadcasting Co., 70 Ohio App. 2d 205, 435 N.E.2d 1131 (1980). While it is true that the public has a great interest in knowing about defamatory statements made by prominent speakers, even if they are directed against private individuals, this approach squarely contradicts the holding in Gertz. 
competing interests of speech and compensation for injury. Equally significant is the requirement in $E d w a r d s$ that the report be "disinterested." The opinion placed great emphasis on the fact that the defendant newspaper had included exculpatory information in its news story-denials by the defamed parties of the charge against them. ${ }^{69}$ This requirement of evenhandedness is important in two respects. By mitigating the damage done by the publication of a false statement, it moves the balance back toward the protection of reputation. In addition, it captures for the reader the value of false attributed speech by alerting him that such speech may be false.

\section{B. Evenhandedness and Protecting Reports of Rumor}

By limiting its protection to statements by responsible and prominent speakers, $E d w a r d s$ failed to assist the publisher of rumor, since by definition a rumor lacks a definite source, much less a prominent or responsible one. ${ }^{70}$ But as it is currently designed, the $E d w a r d s$ test would be ill-suited to apply in cases in which the attribution takes an unorthodox form such as rumor. The $E d w a r d s$ requirement for the inclusion of exculpatory information is minimal; as described in $E d w a r d s$, it seems to apply only to exculpatory information in the reporter's possession. ${ }^{21}$ The court rejected the suggestion that the publisher investigate the veracity of a speaker's statement: "Nor must the press take up cudgels against dubious charges in order to publish them without fear of liability for defamation." be argued that if a publisher knew that the statement of a prominent, responsible speaker was false, the publisher should be obligated to investigate the statement further. But knowledge of falsity is rarely absolute, and so the court was probably justified in allowing some leeway for reliance

\section{Edwards, 556 F.2d at 120.}

70. Cf. Comment, Constitutional Privilege to Republish Defamation, supra note 61, at 1276-77 (irresponsible and litle-known speakers can play roles in newsworthy events as important as roles played by responsible and prominent speakers). But $c f$. Note, supra note 61 , at 637 (rejecting privilege protecting republication of any statement as creating unacceptable risk of abuse).

71. See Weingarten v. Block, 102 Cal. App. 3d 129, 148, 162 Cal. Rptr. 701, 714 (1980) ("Even an author whose function is to gather facts need not necessarily verify his information."), cert. denied, 449 U.S. 899 (1980); Krauss v. Champaign News Gazette, Inc., 59 Ill. App. 3d 745, 747, 375 N.E.2d 1362,1363 (1978) (under doctrine of neutral reporting, journalist "need inquire no further"); Comment, Constitutional Privilege to Republish Defamation, supra note 61, at 1281 (Edwards does not require strict editorial balance but may require publisher to mention information in possession contradicting published statement).

In Cianci v. New Times Publishing Co., 639 F.2d 54 (2d Cir. 1980), the court seemed to read a more stringent requirement of evenhandedness into Edwards. Yet the focus of the court's concern still was on exculpatory information within the publisher's possession rather than on a need to conduct further investigation. Id. at 62; see also Comment, Restricting the First Amendment Right to Republish Defamatory Statements, supra note 61, at 1503-06 (discussing Cianci's treatment of requirement of evenhandedness).

72. Edwards, 556 F.2d at 120. 
on the speaker's status.

In contrast, a rumor, by its very nature, should raise doubts in the publisher's mind about its veracity. Since rumor is known to have an uncertain factual basis, a republication privilege could reasonably require the publisher to "take up cudgels" against such speech through further investigation while adopting a more lenient view toward statements by prominent speakers. Furthermore, in cases typified by $E d w a r d s$, the defamed may still have recourse against the original speaker if the privilege is invoked. ${ }^{73}$ But if the defamatory statement is attributed to rumor, the plaintiff must sue the publisher or no one at all. Therefore, the defamed party's interest in protecting his reputation also dictates that a higher standard of evenhandedness be imposed on the publisher of rumor.

This discussion suggests that a comprehensive republication privilege should contain a requirement of evenhandedness that varies according to the type of attribution, with a stronger requirement applied to unreliable sources such as rumor. A republication standard could achieve this result by tying the requirement of evenhandedness to the "knowing falsity" requirement of the current actual malice test. ${ }^{74}$ Under such a proposal, the publisher would be required to communicate any knowledge of falsity he has acquired concerning the attributed information. ${ }^{75}$ His knowledge of falsity would be measured according to the actual malice standard, that is, according to whether the publisher knew the statement was false or acted with reckless disregard of whether it was false or not. ${ }^{76}$ One factor in

73. Cf. Edwards, 556 F.2d at 119 (suit filed against source of allegedly defamatory statements and newspaper); Catalano v. Pechous, 83 Ill. 2d 146, 419 N.E.2d 350 (1980) (plaintiff granted summary judgment against originator of statement; publisher protected from suit by lack of actual malice), cert. denied, 451 U.S. 911 (1981).

74. Obviously, if the publisher were not found to have knowledge of falsity, he would not be liable under the Sullivan-Gertz line of cases and would not need the protection of the proposed privilege. Therefore, it makes sense for the republication privilege to incorporate the actual malice standard.

75. The method of communicating falsity under the proposed standard would be left to the reporter's discretion. Among the alternatives available to him would be printing the information that contradicts the statement, reporting the unreliability of the sources, or allowing the defamed party to respond.

An objection to this requirement of evenhandedness may be that it is analogous to imposing a "right of reply" on a newspaper in contravention of Miami Herald Publishing Co. v. Tornillo, 418 U.S. 241 (1974). In Tornillo, the Court struck down a Florida statute that required a newspaper to grant a political candidate a "right of reply" if the newspaper published defamatory material about the candidate. The Court disapproved of this effort to instruct a newspaper on what to print, reasoning that such instructions were only slightly removed from censorship. While the proposed republication standard does not require that a newspaper publish material presenting the defamed party's side, a standard that hinges what could be substantial liability on whether the report is balanced may seem different only in form. Yet Tornillo is distinguishable. Tornillo involved a statute that created a "right of reply" based on any defamatory publication. Under the proposed privilege, a publisher would be required to print additional information only when he knows his publication is false; without the exculpatory information, the publication is of no value to the reader and should be discouraged.

76. The actual malice test-a scienter requirement based on the state of mind of the publisher-requires proof of subjective awareness. This test has been criticized for raising difficult evidentiary problems, see Robertson, supra note 59, at 238, and for encouraging discovery which interferes 
detemining reckless disregard is the trustworthiness of the source. The less reliable the source, the greater is the likelihood that the reporter will be found to have knowledge of falsity-in some cases, owing merely to the source itself. ${ }^{77}$ Consequently, the reporter citing unreliable sources would be more likely to be found to have knowledge of falsity and therefore would have a greater incentive to investigate further and to include exculpatory information in order to retain his privilege.

In illustration, consider the prominent, responsible speaker and rumor. There is nothing about the responsible and prominent speaker as a source that would put the publisher on notice that his statement is false. Thus, the publisher would not be obligated to conduct his own research into the statement's veracity in order to retain the privilege. But if information came to the publisher's attention suggesting that the statement was false, he would then be obligated to include that information in his news story. This result is identical to that achieved under the Edwards privilege. In contrast, the publisher who prints a story based on rumor and does nothing more than attribute the story to rumor would lose the proposed privilege. Knowledge of falsity would be assumed from the nature of the source itself; to retain the privilege, the publisher must investigate the rumor and report the results of that investigation. ${ }^{78}$ In this case, the proposed standard is much stronger than Edwards.

After investigating the information provided by an unorthodox source, the publisher still must communicate clearly what his research has uncovered. ${ }^{78}$ If the publisher finds no information that contradicts his source, he

in the editorial process, see Oakes, Proof of Actual Malice in Defamation Actions: An Unsolved Dilemma, 7 HOFSTRA L. REV. 655 (1979). In most circumstances, these same problems would arise under the proposed standard. But in cases in which the falsity of the statement is acknowledged in the publication, the reporter's state of mind would already have been revealed, and the proposed standard would require only that the publication be compared with the body of facts from which the reporter wrote the story.

77. See supra p. 95.

78. The proposed standard should have little impact on the work habits of the vast majority of journalists; the evenhandedness that the standard requires is less stringent than the level of fairness most reporters seek as a matter of professional pride. In some cases, however, it may result in more thoroughly researched stories, since it will lessen the incentives created by the current actual malice test not to investigate defamatory material thoroughly. See St. Amant v. Thompson, 390 U.S. 727, 731 (1968) (actual malice test "encourages the irresponsible publisher not to inquire"); Robertson, supra note 59, at 240 ("The logic of St. Amant is, the less a publisher knows about the subject of an article, the belter."). The incentive exists because of the scienter requirement of actual malice; if the reporter does not investigate further, he will not discover that what he has learned is false. Under the proposed standard, the reporter, upon discovering information that contradicts the statement he plans to republish, need only include that information in his story to avoid liability. There is no incentive not to investigate further.

79. Efforts to communicate falsity should not be judged too strictly. Just as a plaintiff must prove knowledge of falsity or reckless disregard with convincing clarity, he should also be required to show a wide divergence between the reporter's knowledge of falsity and the evidence of falsity included in the story before liability is found.

For example, the proposed standard would take into account the difference between a reporter who 
can satisfy the proposed standard by describing in the story the source and its unreliable character. For example, in Burns v. Times Argus Associa$t^{i o n},{ }^{80}$ the defendant newspaper published an article describing an anonymous allegation made against the wife of a public official and gubernatorial candidate. In its story, the newspaper revealed that the allegation had been made anonymously and noted that the allegation could be part of a campaign to discredit the plaintiff's husband in his election bid. ${ }^{81}$ This would constitute a description sufficient to retain the proposed privilege. But reporting the source's unreliability would not be sufficient if the publisher had other information that established the statement's falsity. For example, the Washington Post did not believe the rumor that President Garter had bugged Blair House. Although its report of the story was labeled a rumor, that label alone, while putting the reader on notice that he should read the item with some skepticism, left open the possibility that the item was true. Under the proposed standard, the Post would not be found to have communicated adequately its knowledge of falsity. ${ }^{82}$

\section{Conclusion}

Absent legal considerations, a journalist will use rumor and other unorthodox sources only when the newsworthiness of the information they provide outweighs the problems that the use of such sources creates. The legal standards of liability under current libel law, however, do not recognize that valuable information may be gained from these sources and therefore restrain their use excessively. The proposed standard would allow greater use of reports based on rumor but would require the printing

has rebuttal evidence on hand and a reporter who has to dig for such evidence under deadline pressure. While the reporter facing a deadline may suspect the veracity of a statement, he may not be able to reach the defamed party for comment until the deadline has passed. In such cases, the court should look to see if the exculpatory information was printed in a timely manner (such as the next day's newspaper), rather than requiring it to be printed in the same story as the defamatory statement.

80. 139 Vt. 381,430 A.2d 773 (1981).

81. Id. at $383,430 \wedge .2 \mathrm{~d}$ at 774 . The Vermont Supreme Court found that the story was published without actual malice and therefore upheld the granting of the newspaper's motion for summary judgment. Id. at $389-90,430 \mathrm{~A} .2 \mathrm{~d}$ at $777-78$. The court's finding was questionable, given the treatment of anonymous sources under current actual malice doctrine. See supra p. 95 . The court also cited Edwards to support its holding, id., although a story based on an anonymous source would fall outside the Edwards standard. Cf. Paquette v. Vanguard Publishing Co., 8 MEDIA L. REP. (BNA) 2243 (Vt. Super. Ct. 1982) (extending privilege to news stories based on confidential sources).

82. A reporter who attributes statements to a confidential source would not be able to claim protection under the proposed standard. The demands of confidentiality prevent the reporter from publishing the full context of the attributed statement, lest he reveal his source's identity. Consequently, the reader cannot independently evaluate the statement's value; he must rely on the reporter's evaluation of the statement as revealed by the reporter's decision to publish it. Therefore, the reporter should be viewed as assuming responsibility for the statement and should be held liable for knowledge of the underying truth or falsity of the statement. But see Paquette v. Vanguard Publishing Co., 8 MEDIA L. REP. (BNA) 2243 (Vt. Super. Ct. 1982) (applying neutral reporting privilege to news story based on confidential sources). 
Libel and Rumor

of exculpatory information known to the reporter, both to enhance the value of such reports to the reader and to minimize their damage to reputation. 